\title{
THE IMPACTS OF HUMAN AND AGRICULTURAL ACTIVITIES ON THE GROUNDWATER QUALITY IN MOSTOROD ABU ZABAL AREA, EAST NILE DELTA, Egypt
}

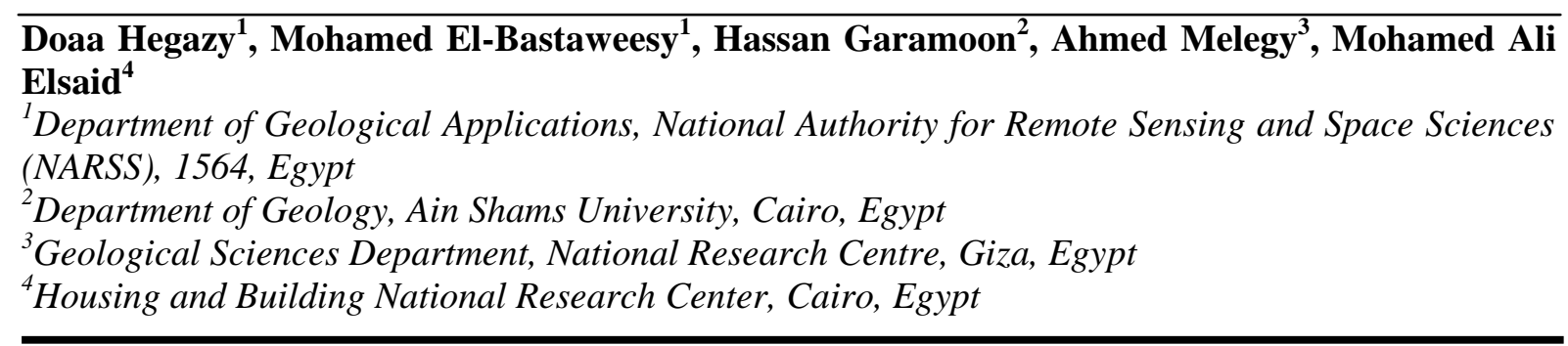

\begin{abstract}
East of Nile Delta is an important region for agriculture in Egypt, where some problems appeared because of increasing population, decreasing Nile water, excessive pumping of groundwater and irrigation with drainage water. The groundwater quality and quantity in the eastern Nile Delta are highly affected by urbanization, industrial and agricultural activities. In the present study, sixteen groundwater samples were collected from the Quaternary Nile aquifer and the surrounding irrigation canals and drains were sampled too. Also, satellite images (Landsat 8, GeoEye and SRTM) were used to create a landuse map 2018 and to assess the expansion of urban and industrial settlements on the cultivated lands in the eastern Nile Delta. The landuse map shows random increase of industrial settlements along irrigation canals. The groundwater samples are analyzed for major ions, nitrates, and trace elements, in addition to detection of Coliform group. Results of chemical analyses show three hydrochemical facies of groundwater including, namely $\mathrm{Na}-\mathrm{Cl}, \mathrm{Mg}\left(\mathrm{HCO}_{3}\right)_{2}$ and a mixed type. The analyzed hydrochemical parameters indicate wide ranges of TDS (320 -1860 mg/l), $\mathrm{Na}^{+}$(42.7-797 $\mathrm{mg} / \mathrm{l}), \mathrm{NO}_{3}^{-}$(4-163 mg/l), $\mathrm{Mg}^{2+}\left(11.5-122 \mathrm{mg} /\right.$ ) and $\mathrm{Cl}^{-}(38.3-686 \mathrm{mg} / \mathrm{l})$ suggesting complex hydrochemical processes and recharge from multiple sources. TDS, $\mathrm{Pb}, \mathrm{Fe}, \mathrm{Zn}, \mathrm{Cl}, \mathrm{Mg}$, and $\mathrm{Na}$ exceed the limit of the World Health Organizations standards for drinking water quality in the northeastern part of the study area. Spatial analysis of the landuse map shows that high concentrations of $\mathrm{Pb}, \mathrm{Zn}$ and $\mathrm{Fe}^{2+}$ are most likely related to contamination from industrial sewage. High nitrate concentrations beyond the permissible limit (50 $\mathrm{mg} / \mathrm{l})$ were reported near the drains and associated with high concentrations of the total Coliform count various from 2 to 43 CFU/100 $\mathrm{ml}$ indicating a potential mixing between the domestic sewage and returned irrigation water to the groundwater system.
\end{abstract}

Keywords: Groundwater Quality, Human Impacts, Remote Sensing, Coliform group, East Nile Delta, Egypt

\section{INTRODUCTION}

Groundwater is considered as one of the main fresh water resources available in Egypt. The increasing population in the Nile Delta leads to a wide variety of anthropogenic activities, including transportation networks, residential domestic waste, and sewage sludge effluents originating from within or from nearby urban areas, potentially toxic elements, are being dispersed in the soil, water and air. Various methods and technologies are used to measure, monitor and evaluate groundwater quality such as hydrogeochemical and bacteriological analyses. Remote sensing (RS) and geographic information system (GIS) tools play vital roles in the spatial integration of various data sets.

The present work aims to evaluate the impact of hydrogeological conditions and human activities on shallow groundwater quality in eastern Nile Delta. To achieve this purpose, field and laboratory measurements were carried out for the collected groundwater samples. The samples were analyzed for major ions, nitrates, and trace elements, in addition to detection of Coliform group also done. Remote Sensing and GIS techniques were also used to produce landuse map for the year 2018 in order to evaluate the connection between land use activity and water quality in the study area. 


\section{Location of study area}

The area under investigation extends between Mostorod and Abu Zaabal in AlQalyubia Governorate, southeastern part of the Nile Delta, Egypt. The area is bounded by longitudes $31^{\circ} 14^{\prime} 52^{\prime \prime}$ and $31^{\circ} 25^{\prime} 24^{\prime \prime} \mathrm{E}$ and latitudes $30^{\circ} 7^{\prime} 32^{\prime \prime}$ and $30^{\circ} 18^{\prime} 25^{\prime \prime} \mathrm{N}$ (Fig. 1). It covers an area of approximately $209 \mathrm{Km} 2$.

\section{MATERIAL AND METHODS}

Sixteen groundwater samples were collected through four field trips between January and February 2018 from western and eastern side of the Ismailia canal. The groundwater samples were analyzed for major ions, and trace elements in addition to detection of Coliform group also done. The analysis was conducted in the water and air laboratory in the central laboratory of Egyptian Mineral solids (TDS) by evaporated and dryness at $180 \mathrm{o}$ C. The $\mathrm{pH}$ was measured by using a laboratory $\mathrm{pH}$ meter model MP230 German with an accuracy of $\pm 1 \%$. Major cations Calcium $(\mathrm{Ca} 2+)$ and Magnesium $(\mathrm{Mg} 2+)$ and major anions Bicarbonate (HCO3-), Carbonate (CO32-) and Chloride (Cl-) were detected by volumetric method. Sodium $(\mathrm{Na}+)$ and Potassium $(\mathrm{K}+)$ were detected by using atomic absorption (Thermo Fisher Scientific) model ICE 3000 SERIS. Sulphate (SO42-) was determined by turbid metric were done by using Spectrophotometer model UV-160A UVVisible Recording, Spectrophotometer Shimadzu. Nutrients (PO43-, NH4+) were analyzed using ammonia selective electrode model ISE Digital DM-21, NO3- was determined by using spectrophotometer. The trace elements ( $\mathrm{Fe}, \mathrm{Mn}, \mathrm{Cu}, \mathrm{Cd}, \mathrm{Ni}, \mathrm{Co}, \mathrm{Pb}, \mathrm{Cr}$,

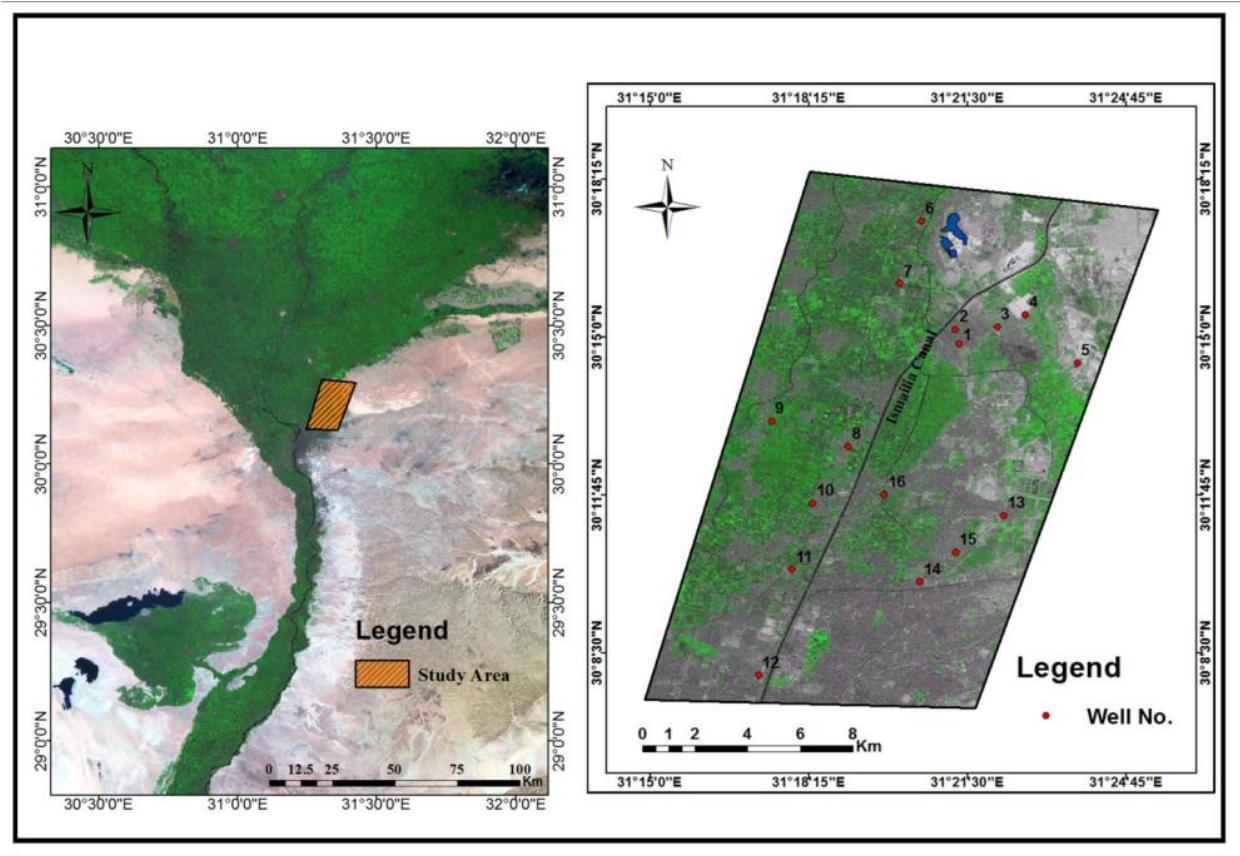

Figure (1): Location and groundwater samples map of the study area.

Authority and Mining Projects (EMRA) with assistance of the staff of the laboratory following the Standard Methods for the Examination of Water and Waste water; (APHA, AWWA, WEF, 2005) which include physical parameter of groundwater samples such as electrical conductivity (EC) which was measured by EC meter model YSI 33, U.S. with an accuracy of $\pm 1 \%$ and total dissolved
As) were determined by using I.C.P. (Inductive Coupling Plasma) Agilent 720. Total and fecal coliforms and total bacterial counts at $22^{\circ} \mathrm{C}$ and at $37^{\circ} \mathrm{C}$ were determined according to (APHA, 2017). The membrane filter (MF) technique was used to determine total and fecal coliforms and fecal streptococci in $100 \mathrm{ml}$ sample. Pour plate method was used for total bacterial count. 


\section{Geologic setting}

Several studies have investigated the geological setting and stratigraphical sequence of the eastern Nile Delta throughout the last sixty years, including Shukri and Akmal (1953), Shukri and ElAyouti (1956), Said (1962), Metwalli (1963), Shata and El Fayoumy (1970), ElDiary (1980) and RIGW (1989). The exposed sequence in the study area consists of sedimentary and volcanic rocks ranging in age from Oligocene to Quaternary (Fig. 2). These rock units include from bottom to top:

\section{1- Oligocene}

Basalt sheets (highly weathered with grey to greenish color) belong to Upper Oligocene and is exposed at Abu Zaabal Quarries with an average thickness of $30 \mathrm{~m}$. The basalt sheets encounter also at variable depths and appear to be structurally controlled.

\section{2- Pliocene}

The Pliocene sediments are exposed at the eastern part of the area under study. Hagul Formation sandy limestone and marl of Pliocene age that are rich in Ostrea cocullata and algal remains. The subsurface sediments are formed of clay, sand, gravely sand with limestone interbeds. The Pliocene clay is overlain by the Quaternary deposits with an average thickness of $200 \mathrm{~m}$.

\section{3-Miocene}

The Miocene sediments are composed of course sand and gravel with limestone intercalations. The thickness of these sediments reaches $40 \mathrm{~m}$ in their outcrops at El Menaiyer Quarries. The recorded subsurface Miocene sediment in Ismailia canal environs is $225 \mathrm{~m}$ in thickness.

\section{4- Quaternary}

\subsection{Prenile sediments}

According to Said (1981), the Prenile River reached Egypt during the Middle Pleistocene drawing its water from the Ethiopian Highlands through Atbara and the Blue Nile Rivers. The Prenile deposits are composed of massive cross bedded sands interbedded with two conglomeratic beds which are derived from the Red Sea Hills (Paulissen and Vermeersch, 1987) and are called Abbassia I and II respectively with silt beds intercalations that are named as Dandara Formation.

\subsection{Aeolian deposits (Sand dunes)}

The study area involves two types of sand dunes; (1) seif (longitudinal) dunes of wide extent and high altitude and the barchan dunes of small extent and low relief (Said, 1990). Both sand bodies are named El-Khanka sand dunes which stretch out through the low land of the Heliopolis depression

\subsection{Neonile sediments}

These units are lithologically composed of fluvial deposits with interfingering dune sands, silts and marls. The Neonile sediments in the study area are characterized by dense cultivation, because they represent flat highly fertile areas. During the period from 400,000 years ago to the present, great climatic changes have affected the rainfall on the headwaters of the Nile, together with the tectonic activity resulted in the decreasing of the water supply and the capability of the river to load sediments (Abotalib and Mohamed, 2013).

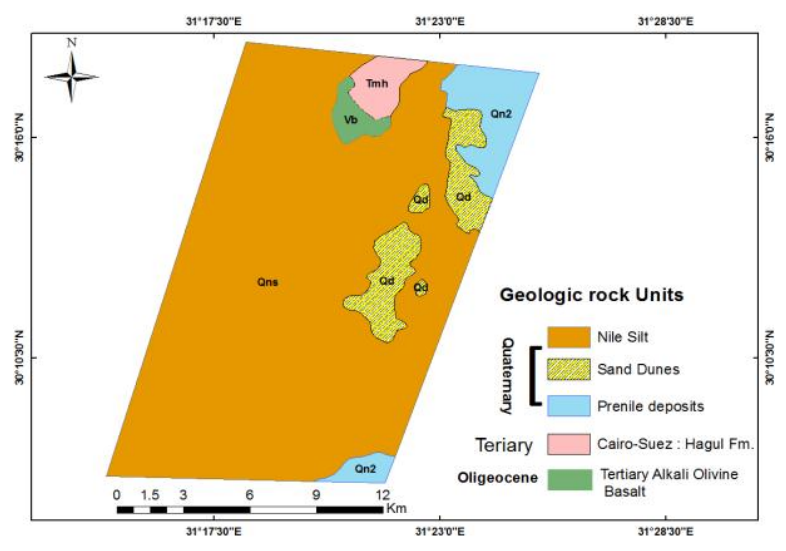

Figure (2): Geological map showing the geological unites exposures in the study area (CONOCO,1987).

\section{Hydrogeological setting}

Hydrogeological setting of the study area is investigated through the study of two hydrogeological cross sections A-A', B-B' from west to east (RIGW, 1989) and 
hydrogeological map of the study area (RIGW, 1992) Figs. (3 and 4).

\section{The Quaternary Aquifer}

The Quaternary aquifer represents the main groundwater aquifer in the study area. It has a wide geographic distribution and high productivity. The thickness of this aquifer increases gradually from south to north and northwest, it ranges from 100 to $300 \mathrm{~m}$. It is divided into two subunits namely; the Pleistocene aquifer and Holocene aquitard. The two subunits can be described as follows:

\subsection{Holocene Aquitard}

The Holocene silt unit crops out at the surface east and west Ismailia canal consisting of silty and sandy clay. It is underlined by the Pleistocene deposits as shown in Fig. (3). It has a reduced thickness, ranges between $0 \mathrm{~m}$ at the eastern portions to $20 \mathrm{~m}$ at the southwestern part of the investigated area. The changes of lithological composition and thickness of this unit makes the Pleistocene aquifer more vulnerable to contamination (El-Fakharany and Mansour, 2009) as shown in Fig. (4).

\subsection{Pleistocene Aquifer}

The Pleistocene aquifer is the main aquifer in the study area and it is composed of graded sand and gravels with intercalated clayey sand. The thickness of the Pleistocene deposits ranges between 70 and $100 \mathrm{~m}$. The groundwater of Pleistocene aquifer is continuously recharged from infiltrating surface water. Infiltration takes place directly from the canals and drains cutting the area and indirectly through the irrigation water surplus.

\section{Tertiary Aquifer}

The Tertiary aquifer can be divided into three subunits namely; the Miocene, the Pliocene and the Oligocene and can be described as follows:

\subsection{Pliocene Aquiclude}

The Pliocene aquiclude is present in the form of sand and gravels intercalated with clay and exposed on the surface covering small area west of Billbis drain as shown in Fig. (3).

\subsection{Miocene Aquifer}

Miocene aquifer is mainly composed of gravels with limestone interbred and coarse sand. The Miocene aquifer is characterized by containing water of marine origin (very saline water) and exposed on the surface covering small area east of Abu Zaabal.

\subsection{Oligocene Aquifer}

The Oligocene basalt extends from west under Ismailia canal to east and underlies the Quaternary, Pleistocene and the Tertiary Miocene deposits, as shown in cross section (B$\left.B^{\prime}\right)$ which shows that another deposit of the Oligocene consisting of gravel and sand underlies the basalt rock in the southern part, Fig. (3).

The hydrogeological conditions developed in Abu Zaabal Quarries such as deepening of the Quarries and removal of basaltic sheet is associated with continues groundwater flow either from the Oligocene aquifer or seepage from the Ismailia canal lead to the development of a water pond filled with brackish water. The development of such pond may impair groundwater quality of the Quaternary aquifer due to the existence of the faults and joints, which facilitate the hydraulic connection between the existed surface water in the pond and the groundwater in the Quaternary aquifer.

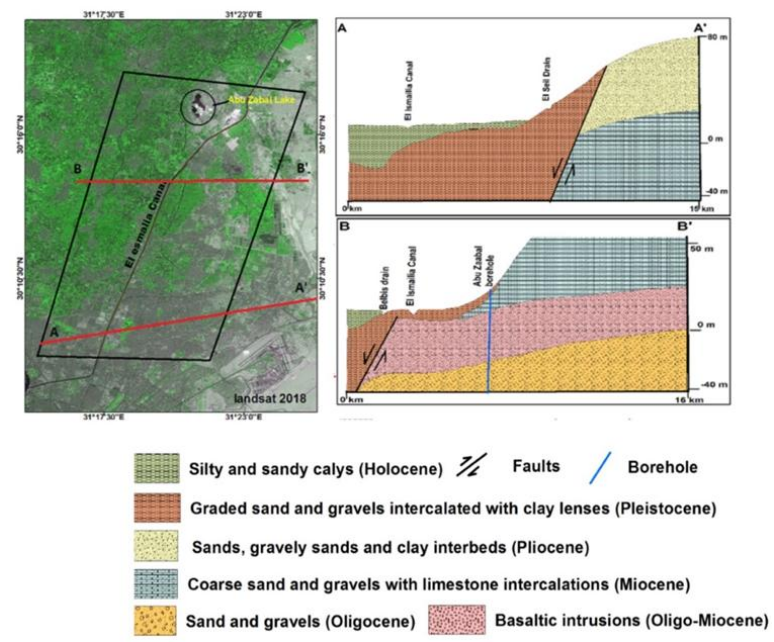

Figure (3): Hydrogeological cross sections at various locations (RIGW, 1989). 


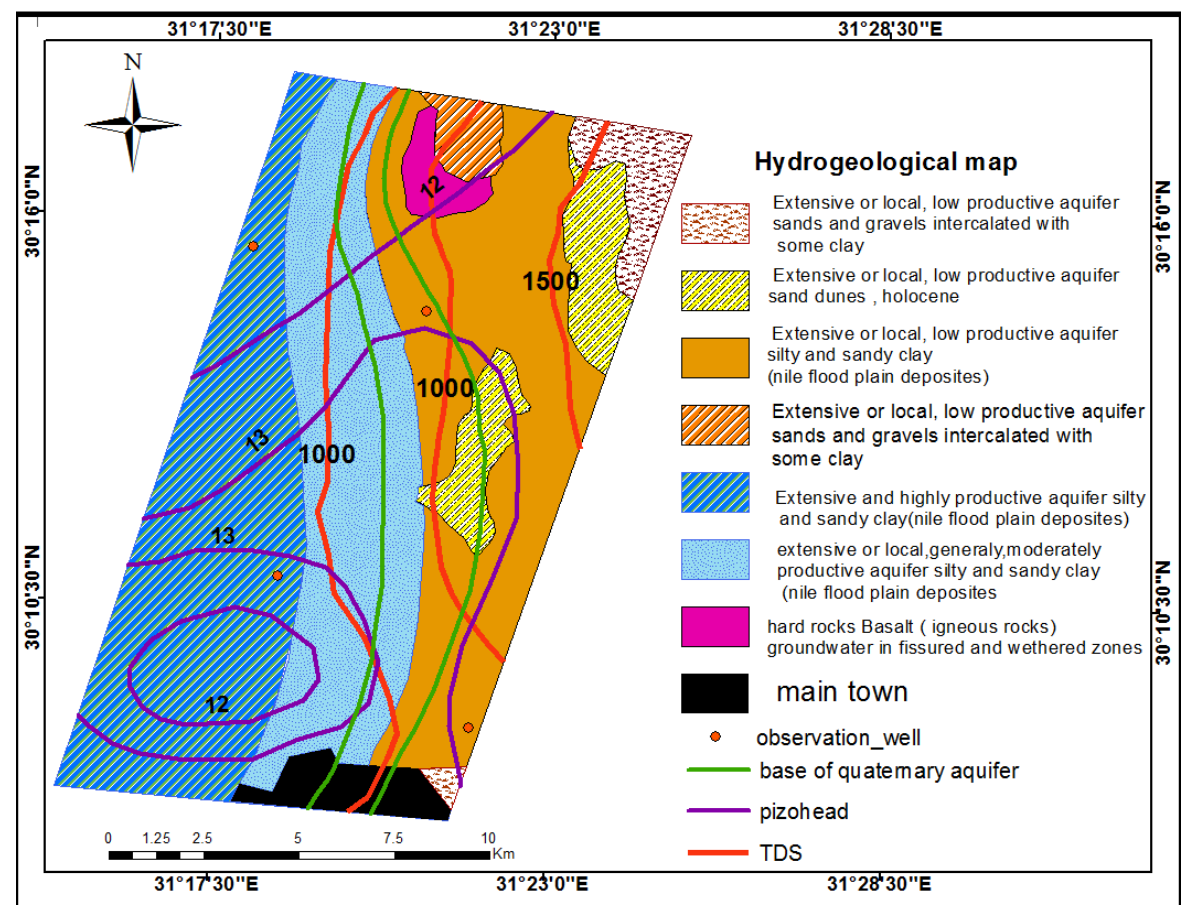

Figure (4): Hydrogeological Map of study area (modified after RIGW, 1992).

\section{RESULTS AND DISCUSSION}

The chemical analysis results of 16 shallow groundwater samples collected through the east and west of Ismailia canal are discussed through two main topics (Table1). Hydrochemical aspects include water salinity, total hardness and ion dominant as well as water pollution which can be divided according to the pollutant type into four types such as chemical inorganic, biological, organic and bacteriological pollutants.

\section{Hydrochemical aspects}

\subsection{Water salinity}

The shallow groundwater of the study area classified as fresh to brackish water, where the total dissolved salts ranges from 320 to 3862 $\mathrm{mg} / \mathrm{l}$ with a mean value of $1364 \mathrm{mg} / \mathrm{l}$. The areal distribution of the salinity content in shallow groundwater wells. Figure 6 shows that the southwestern part of the study area is characterized by good potable water of low salinity (TDS < $500 \mathrm{mg} / \mathrm{l}$ ). These zones surrounded by a major zone characterized by fresh water ranges between 500 and $700 \mathrm{mg} / \mathrm{l}$. The middle part of study area characterized by fairy fresh water ranges between $700-1500 \mathrm{mg} / \mathrm{l}$ (Chebotarev's, 1955a,b). The low salinity is due to the recharge from the Pleistocene aquifer from Ismailia canal, irrigation processes and high salinity is attributed to leaching and dissolution of aquifer matrices. The north parts of the aquifer classified as brackish zones where the salinity content more than $1000 \mathrm{mg} / \mathrm{l}$ which exceeds the permissible limits for drinking (WHO 2004).

\subsection{Total hardness}

Water hardness in most groundwater is naturally occurring from weathering of limestone, sedimentary rock and calcium bearing minerals such as calcite, gypsum and dolomite. Hardness can also occur locally in groundwater from chemical and mining industry effluent or excessive application of lime to the soil in agricultural areas. If the groundwater aquifers containing limestone minerals such as calcite $(\mathrm{CaCO} 3)$ and dolomite (CaMgCO3), hardness and alkalinity will be high. The maximum permissible limit of total 
Table 1: Chemical analysis of the water samples

\begin{tabular}{|c|c|c|c|c|c|c|c|c|c|c|c|c|c|c|c|}
\hline S.No & $\mathrm{PH}$ & $\begin{array}{c}\mathrm{EC} \\
\mu \mathrm{S} / \mathrm{cm}\end{array}$ & $\begin{array}{c}\mathrm{TDS} \\
\mathrm{mg} / 1\end{array}$ & $\begin{array}{c}\mathrm{TH} \\
\mathrm{mg} / 1\end{array}$ & $\begin{array}{c}\mathrm{Ca} \\
\mathrm{mg} / 1\end{array}$ & $\begin{array}{c}\mathrm{Na} \\
\mathrm{mg} / \mathrm{l}\end{array}$ & $\begin{array}{c}\mathrm{Mg} \\
\mathrm{mg} / 1\end{array}$ & $\begin{array}{c}\mathrm{K} \\
\mathrm{mg} / 1\end{array}$ & $\begin{array}{c}\mathrm{HCO} 3 \\
\mathrm{mg} / 1\end{array}$ & $\begin{array}{c}\mathrm{CO} 3 \\
\mathrm{mg} / 1\end{array}$ & $\begin{array}{c}\mathrm{CL} \\
\mathrm{mg} / \mathrm{l}\end{array}$ & $\begin{array}{c}\mathrm{SO} 4 \\
\mathrm{mg} / 1\end{array}$ & $\begin{array}{c}\mathrm{NO} 3 \\
\mathrm{mg} / 1\end{array}$ & $\begin{array}{c}\mathrm{PO} 4 \\
\mathrm{mg} / 1\end{array}$ & $\begin{array}{c}\mathrm{NH} 4 \\
\mathrm{mg} / 1\end{array}$ \\
\hline 1 & 6.8 & 1350 & 786 & 338 & 94.8 & 115 & 24.6 & 20.3 & 363 & 0 & 95 & 177 & 5.5 & 0.9 & 1.3 \\
\hline 2 & 7.35 & 1551 & 874 & 348.7 & 94 & 164 & 27.7 & 16.1 & 478 & 0 & 103 & 179 & 14.4 & 0.086 & 0.9 \\
\hline 3 & 6.81 & 2730 & 1860 & 826.1 & 240 & 292 & 55.1 & 15.8 & 547 & 0 & 303 & 529 & 21 & 0.095 & 1.6 \\
\hline 4 & 7 & 5120 & 3862 & 1189 & 275 & 797 & 122 & 17.1 & 625 & 0 & 686 & 1436 & 4 & 0.123 & 1.4 \\
\hline 5 & 6.7 & 3200 & 2150 & 998.7 & 290 & 304 & 66.7 & 3.84 & 473 & 0 & 541 & 430 & 163 & 0.073 & 3 \\
\hline 6 & 6.7 & 2200 & 1432 & 747.5 & 167 & 220 & 80.3 & 13.2 & 547 & 0 & 302 & 310 & 25 & 0.33 & 1.8 \\
\hline 7 & 7.1 & 3800 & 2896 & 1446 & 393 & 356 & 113 & 13.1 & 439 & 0 & 492 & 1124 & 12 & 0.37 & 2.9 \\
\hline 8 & 7.1 & 1490 & 954 & 287.4 & 77.5 & 211 & 22.8 & 5.93 & 532 & 0 & 59.3 & 221 & 13.5 & 0.48 & 2.6 \\
\hline 9 & 7.12 & 1350 & 910 & 504.6 & 151 & 96.5 & 31 & 7.64 & 428 & 0 & 116 & 178 & 10 & 0.33 & 1.4 \\
\hline 10 & 7.05 & 910 & 552 & 364.3 & 106 & 42.7 & 24.2 & 7.02 & 383 & 0 & 38.3 & 74.1 & 11.7 & 0.47 & 1.8 \\
\hline 11 & 7.08 & 1150 & 750 & 433.1 & 122 & 68.3 & 31.2 & 7.84 & 420 & 0 & 52.5 & 140 & 17.5 & 0.131 & 1.7 \\
\hline 12 & 7.66 & 710 & 320 & 98.02 & 20.3 & 52.8 & 11.5 & 3.12 & 62.2 & 4.8 & 64.7 & 67.9 & 16 & 0.162 & 1.5 \\
\hline 13 & 7 & 1762 & 1128 & 448.8 & 112 & 224 & 41.1 & 7.67 & 472 & 0 & 179 & 256 & 18 & 0.04 & 1 \\
\hline 14 & 6.7 & 1771 & 1134 & 627.7 & 166 & 133 & 51.8 & 15.2 & 390 & 0 & 144 & 356 & 7 & 0.044 & 1.9 \\
\hline 15 & 7.13 & 1878 & 1202 & 341.6 & 92.8 & 275 & 26.7 & 19.4 & 426 & 4.8 & 234 & 288 & 5 & 0.052 & 1.7 \\
\hline 16 & 6.9 & 1593 & 1020 & 314.1 & 94.8 & 229 & 18.8 & 12.8 & 466 & 0 & 109 & 299 & 23 & 0.04 & 2 \\
\hline
\end{tabular}

hardness for drinking purpose is $60 \mathrm{mg} / \mathrm{l}$. Hardness more than $300 \mathrm{mg} / \mathrm{l}$ may cause heart and kidney problems (McGowan, 2000). In the studied area, the total hardness (Table1) ranges from "slightly hard water" to "Excessively hard water". According to the TH classification (Hem, 1970).

\subsection{Ion dominance:}

The ion dominance and relationships between the water chemical analyses are well illustrated by the trilinear of (Piper, 1944). Generally, the water samples appear in upper triangle has secondary salinity properties, where sulfate and chloride exceed sodium and potassium. On the other hand, those which appear in the lower triangle are considered to have primary alkalinity properties, where carbonates and bicarbonates exceed calcium and magnesium.

The results of the analyzed samples were plotted on Piper diagrams (Fig 5). This diagram illustrates three chemically different groundwater facies, namely $\mathrm{Na}-\mathrm{Cl}, \mathrm{Mg}$ $\left(\mathrm{HCO}_{3}\right)_{2}$ and a mixed type. Most of the water samples are located close to each other which indicate that they are of similar origins. In the intermediate area, magnesium and sodium ions represent the main dominating cations, while chloride ions are the main dominating anions.
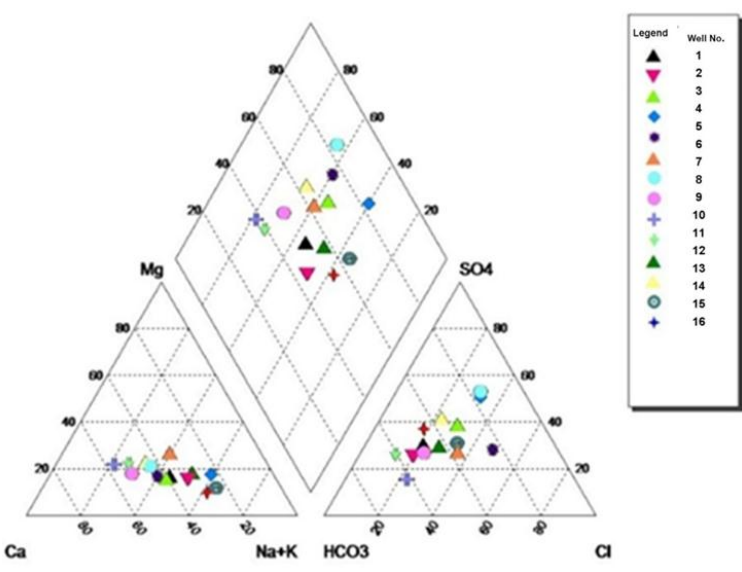

Figure (5): Piper diagram of groundwater samples of the study area. 


\subsection{Major elements distribution}

The major ions $\left(\mathrm{Na}^{+}, \mathrm{K}^{+}, \mathrm{Ca}^{+}, \mathrm{Mg}^{+}\right.$, $\mathrm{CO}^{-2}, \mathrm{HCO}^{3-}, \mathrm{Cl}^{-}$, and $\mathrm{SO}^{-2}$ ) constitute about $80 \%$ of the total mineralization of most water. The composition of groundwater derived mainly from contact between the water and various solids, liquids, and gases. As the groundwater makes its way from its recharge area to discharge area. Chemical analyses data of groundwater samples were tabulated

The areal distribution of sodium, calcium, magnesium, sulfate and chloride contents in shallow groundwater wells (Figs. 7 -10, inclusive) shows the following:

1- The lowest concentrations of these ions noticed beside the Ismailia canal in the center and south part of study area

2- The concentrations of these ions increase in the northern portions of the study area. The probable sources of these high contents of pollutants are mainly due to infiltration of domestic, agricultural and industrial wastes arise from the development of human activities.

3- 3-The sodium content varies from 42.7 to $797 \mathrm{mg} / \mathrm{l}$ (Table, 1). High concentrations of sodium $(>200 \mathrm{mg} / \mathrm{l})$ are recorded at Abu Zaabal.

4- The concentration of sulfate in groundwater ranges between $67.9 \mathrm{mg} / \mathrm{l}$ and $1436 \mathrm{mg} / \mathrm{l}$ in shallow wells. The areal distribution of sulfate content in shallow groundwater (Fig. 9), indicate the high concentration of sulfate found in north part of study area around Abu Zaabal Lake. The lowest concentrations of sulfate noticed beside Ismailia canal in the south part of study area.

5- The chloride contents vary from 38.3 to $686 \mathrm{mg} / \mathrm{l}$ (Table 1). Most of study area is characterized by low chloride concentration $(<250 \mathrm{mg} / \mathrm{l})$. Local polluted zones of high chloride contents recorded at the northern portion of the study area around $\mathrm{Abu}$ Zaabal Lake (Fig. 10).
The discharge of human, animal, industrial wastes and irrigation return flows may add substantial quantity of sodium, chloride and sulfate to groundwater. Consumption of water with high concentrations of sodium may affect persons with cardiac difficulties and hypertension. High concentrations of sulfate and chloride ions (>250 mg/l) may produce objectionable taste and act as laxative on unacclimated users (Hem, 1985 and Probe et al., 1999). Chloride and sulfate ions accelerate the corrosion of metals used in water-supply wells at shallow depths (El-Fakharany et al., 1997).

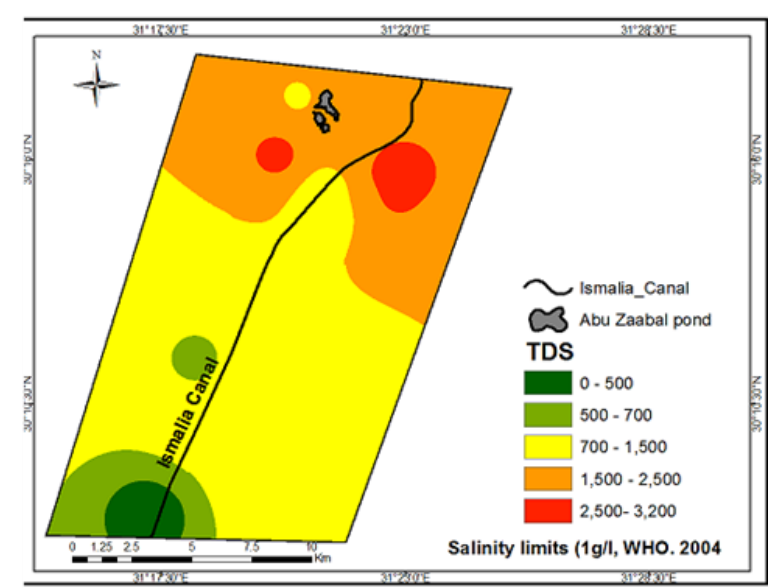

Figure (6): Salinity content distribution map

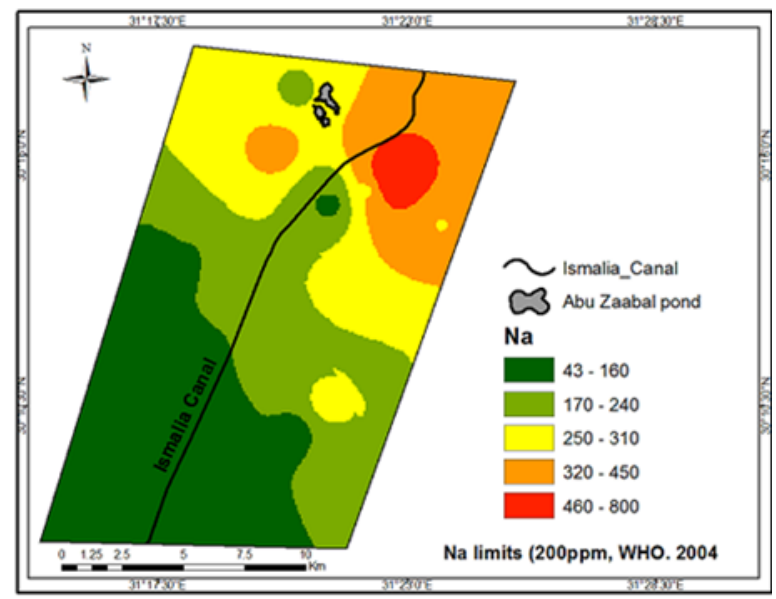

Figure (7): Sodium content distribution map

\section{Water pollution}

Pollution can impair the use of water and can create hazards to public health through toxicity or the spread of diseases. 


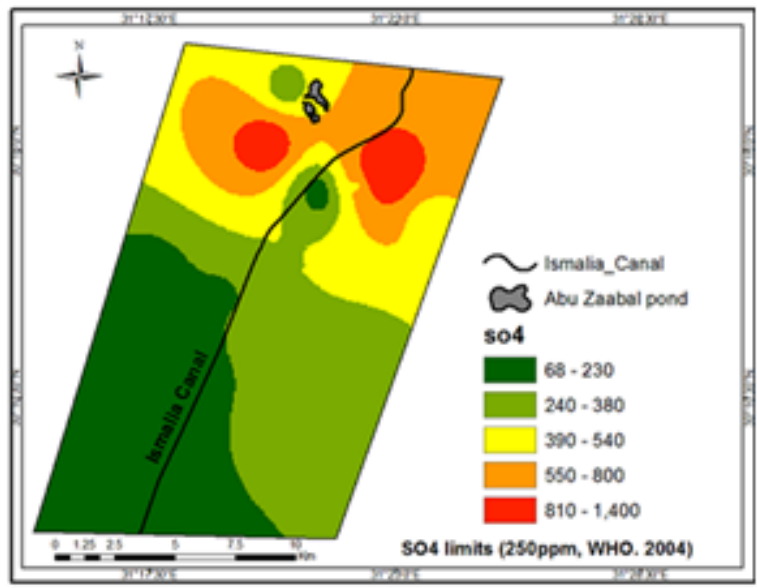

Figure (8): Sulfate content distribution map

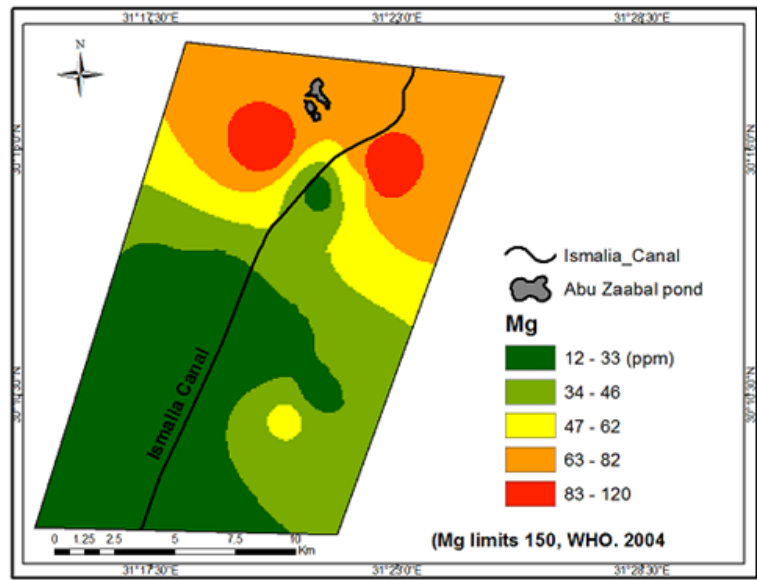

Figure (9): Magnesium content distribution map

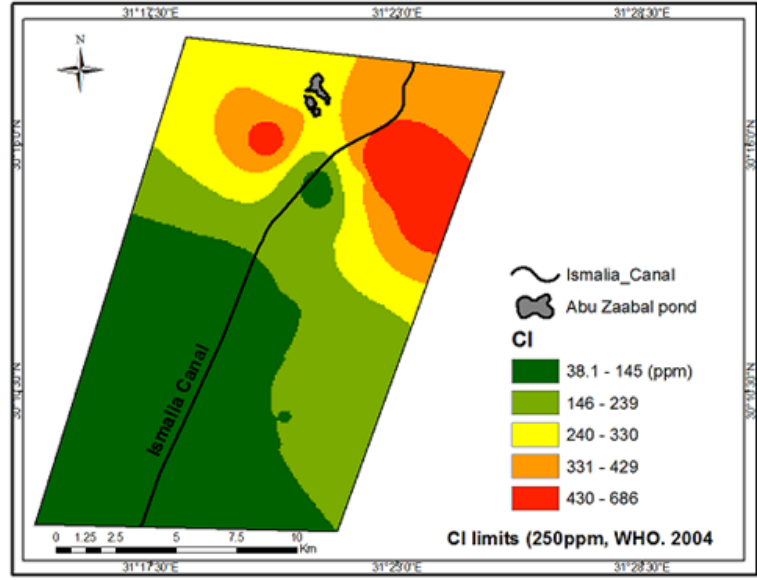

Fig. (10) Chloride content distribution map

Problems of groundwater quality degradation related mainly to natural and human-related factors.

The landuse map of the study area has been created by using satellite images (Landsat 8, GeoEye and SRTM) and Google Earth images, shows the expansion of urban development and random increase of industrial settlements along irrigation canal, Fig. (12).

landuse map used to assess the connection between land use activity and water quality in the study area.

The following discussion based relevant on chemical and bacteriological

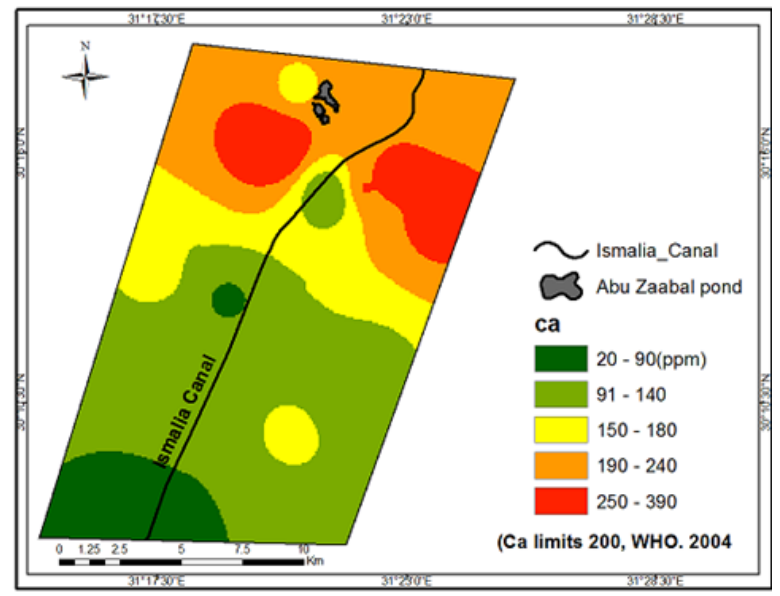

Figure (11): Calcium content distribution map

\subsection{Chemical inorganic Pollutants:}

The chemical inorganic pollutants of water samples in the studied area are discussed through the measurements of trace elements, heavy metals and minor ions, including $\mathrm{Al}^{3+}$, $\mathrm{Cd}^{2+}, \mathrm{Co}^{2+}, \mathrm{Cr}^{3+}, \mathrm{Cu}^{2+}, \mathrm{Fe}^{3+}, \mathrm{Mn}^{2+}, \mathrm{Pb}^{+2}$, $\mathrm{PO} 4^{3}$ and $\mathrm{Zn}^{2+}$.

The recommended maximum concentration of iron in drinking is $0.3 \mathrm{mg} / \mathrm{l}$ (U.S.EPA 2000) to avoid staining. The concentration of iron in shallow groundwater of the Quaternary aquifer ranges between $0.1 \mathrm{mg} / \mathrm{l}$ and $0.8 \mathrm{mg} / \mathrm{l}$.

The shallow groundwater of the Quaternary aquifer is unsuitable for drinking in most of the study area. The concentration of manganese in the shallow groundwater of the Quaternary aquifer ranges between $0.12 \mathrm{mg} / \mathrm{l}$ to $0.3 \mathrm{mg} / \mathrm{l}$ groundwater. Therefore, the concentration of manganese in shallow groundwater is suitable for drinking as the manganese content less than $0.4 \mathrm{mg} / \mathrm{l}$ (WHO, 2004). The concentration of 
aluminum in shallow groundwater of the Quaternary aquifer ranges between 0 to 0.02 $\mathrm{mg} / \mathrm{l}$. Shallow groundwater not exceed Health Organizations standards for drinking (Al less than $0.2 \mathrm{mg} / \mathrm{l}$ ) and still under the permissible limits. $\mathrm{Cu}$ ranges from 0.03 to 0.2 which is lower than the WHO value for drinking water $(2 \mathrm{mg} / \mathrm{l}) . \mathrm{Pb}$ values range from0.1 to 0.3 , which exceed the limit of the World Health Organizations standards for drinking and irrigation water quality (i.e. $0.01 \mathrm{mg} / \mathrm{l}$ ). High values of $\mathrm{Zn}$ are also reported, which range from 1.2 to $3.15 \mathrm{mg} / \mathrm{l}$ exceeding the WHO standards (i.e. $3 \mathrm{mg} / \mathrm{l}$ ).

\subsection{Biological pollutants}

\subsubsection{Nitrogen compounds}

The nitrogen compounds play an important role in many processes that takes place in natural waters. Nitrogen is also one of the basic components of proteins, so it can enter surface waters in sewage and industrial wastewater from the breakdown of proteins and other nitrogenous compounds. Nitrogen fertilizers are used extensively in agriculture, and the excess over crop requirements is mostly leached into drainage water.

\section{A. Ammonia content}

The samples have high concentration of $\mathrm{NH}_{4}$ than the permissible limit $(0.5 \mathrm{mg} / \mathrm{l})$ which ranged from 0.9 to $3 \mathrm{mg} / \mathrm{l}$. The high $\mathrm{NH}_{4}$ concentration is due to sludge of human activity.

\section{B. Nitrate content:}

The collected samples show low nitrate concentrations that ranged from 5 to $25 \mathrm{mg} / \mathrm{l}$ ) than the permissible limit $(45 \mathrm{mg} / \mathrm{l})$ except sample number 4 high values of $163 \mathrm{mg} / \mathrm{l}$. This means that, the oxidation ponds caused reduction processes for the concentration of NO3- ion. This variation may be due to the human activity and excess fertilizer use in agriculture. Noteworthy to mention that $\mathrm{NO}_{3-}$ is considered the final stage of $\mathrm{NH}_{4+}$ oxidation passing with $\mathrm{NO}_{2}$ - in the presence of bacteria and oxygen.

\section{3-Phosphate content:}

Phosphate ions concentration ranges from $0.041 \mathrm{~d}$ level to $0.9 \mathrm{mg} / \mathrm{l}$, table (1). The maximum permissible concentration of phosphate ions in surface water is $1 \mathrm{mg} / \mathrm{l}$ (Dojlido and Best, 1992).

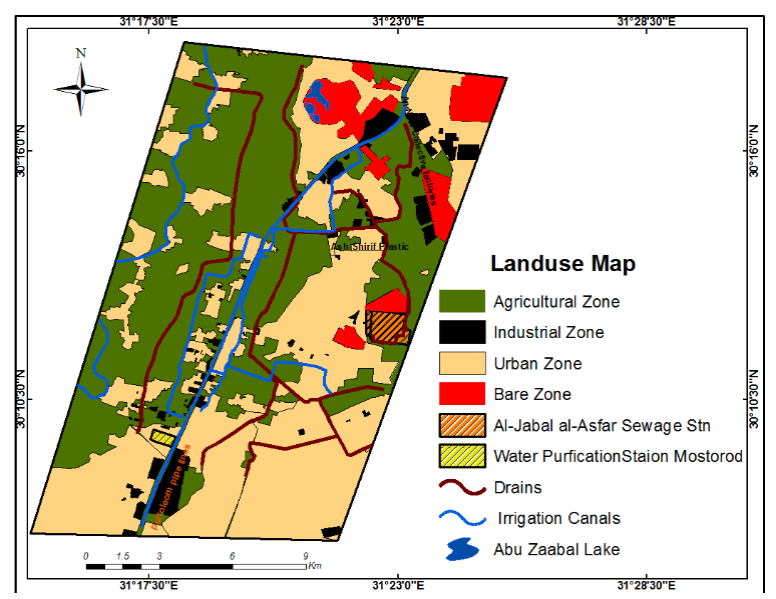

Figure (12): Land use map of study area in eastern Nile delta

\section{Bacteriological pollutant}

The results of bacteriological analyses for the shallow groundwater samples (Table, 2) indicates that the total Coliform CFU /100 ml range from 2 to $43 \mathrm{CFU} / 100 \mathrm{ml}$. Total bacteria count for samples range from 60 to $135 \times 10^{2}$ $\mathrm{CFU} / \mathrm{ml}$. The Fecal coliform ranges between 1 and $15 \mathrm{CFU} / 100 \mathrm{ml}$. The most of samples exceed the recommended value for drinking water is $1 \times 10^{2} \mathrm{CFU} / \mathrm{ml}$ (WHO, 2004).

The sample No. 4 characterized by too numerous to count (TNT) of all bacteria analysis which higher than $300 \mathrm{CFU} / 100 \mathrm{ml}$, APHA, 2017. This sample was taken near to drain and contaminated by animal dung, Fig (13). The presence of coliforms group in most of the water samples generally suggests that some of water samples may have been contaminated with either human or animal origin (Okonko et al., 2008 and Richman, 1997). The total coliform counts of the groundwater samples were grossly contaminated. 


\section{Climate}

The climate in the eastern Nile Delta region is hot, dry and rainless in the summer and mild with some showers in the winter. Mean monthly temperature ranges from about $12{ }^{\circ} \mathrm{C}$ in winter to $29{ }^{\circ} \mathrm{C}$ in summer. Average annual rainfall ranges between 20 and $100 \mathrm{~mm} / \mathrm{yr}$. The daily evaporation varies from approximately $1.5 \mathrm{~mm} /$ day in December to $7.5 \mathrm{~mm} /$ day in July and the evaporation from open water is about $1600 \mathrm{~mm} /$ year (Egyptian Meteorological 2006 and Nosair, 2011).

Table (2) Bacteriological analyses of shallow groundwater samples.

\begin{tabular}{|c|c|c|c|c|c|}
\hline $\begin{array}{c}\text { Sample } \\
\text { No. }\end{array}$ & $\mathbf{T B} \mathbf{3 7}^{\circ} \mathbf{C}$ & $\begin{array}{c}\mathbf{T B} \\
\mathbf{2 2}\end{array}{ }^{\circ} \mathbf{C}$ & TC & FC & F st. \\
\hline 1 & 62 & 83 & 6 & 2 & 0 \\
\hline 2 & 73 & 101 & 13 & 4 & 0 \\
\hline 3 & 69 & 97 & 9 & 6 & 2 \\
\hline 4 & TNT & TNT & TNT & TNT & 0 \\
\hline 5 & 102 & 131 & 24 & 15 & 0 \\
\hline 6 & 135 & 160 & 43 & 19 & 0 \\
\hline 7 & 127 & 144 & 39 & 10 & 2 \\
\hline 8 & 60 & 81 & 10 & 3 & 1 \\
\hline 9 & 66 & 80 & 2 & 1 & 1 \\
\hline
\end{tabular}

TB total bacterial count

TC total coliform

FC fecal coliform

F st. fecal streptococci

\section{SUMMARY AND CONCLUSIONS}

The hydrogeological connection between the surface water and the Pleistocene aquifer in the Nile Delta and the composition of aquifer material (gravels and sands) results in a quick response to the contamination from domestic, industrial sewages, excessive use of pesticides and chemical fertilizers. To assess this quick response of contamination, sixteen groundwater samples were collected and analyzed tapping the shallow Pleistocene aquifer. They were analyzed for physical, chemical and bacteriological characteristics. The results have been integrated with a landuse map derived from 2018 satellite imagery.

The $\mathrm{pH}$ values range from 6.7 to 7.66 and EC values range from 710 to $5120 \mu \mathrm{S} / \mathrm{cm}$. The lowest concentrations of major ions (less than 500 to $1500 \mathrm{mg} / \mathrm{l}$ ) are reported in the surroundings of the Ismailia canal in the central and southern parts of study area. On the other hand, the northern part of the study area is characterized by elevated values of these major ions (up to 3200). The source of these high concentrations is probably related to infiltration of domestic, agricultural and industrial wastes arise from the development of human activities. Three chemically different groundwater facies, namely $\mathrm{Na}-\mathrm{Cl}, \mathrm{MgHCO} 3$ and a mixed type are reported. Results of trace and heavy elements show that values of $\mathrm{Fe}$ (up to $0.8 \mathrm{mg} / \mathrm{l}$ ), $\mathrm{Pb}$ (up to $0.01 \mathrm{mg} / \mathrm{l}$ ) and $\mathrm{Zn}$ (up to $3.15 \mathrm{mg} / \mathrm{l}$ ) exceed the limit of the World Health Organizations standards for drinking and irrigation water quality, while the values of $\mathrm{Mn}$ (from 0.12 to $0.3 \mathrm{mg} / \mathrm{l}$ ), $\mathrm{Al}$ (from 0 to $0.02 \mathrm{mg} / \mathrm{l}$ ) and $\mathrm{Cu}$ (from 0.03 to $0.2 \mathrm{mg} / \mathrm{l}$ ) are within the permissible limits for drinking and irrigation purposes. Landuse map from 2018 satellite imagery shows that the high values of $\mathrm{Pb}, \mathrm{Fe}$ and $\mathrm{Zn}$ are spatially correlated with areas of random expansion in the establishment of factories along the course of the Ismailia canal. Bacteriological analyses indicate that the total Coliform CFU/100 ml range from 2 to 43 CFU/100ml, which are higher than the recommended value $\left(1 \times 10^{2} \mathrm{CFU} / \mathrm{ml}\right)$ and total bacteria count for samples range from 60 and $135 \times 10^{2} \mathrm{CFU} / \mathrm{ml}(\mathrm{WHO}, 2004)$. The present study shows that the northern part of the study area is relatively polluted and further investigation and assessment of the pollution pattern and sources using integrated remote sensing, chemical and geostatistical modeling are highly recommended. 


\section{REFERENCES}

Abotalib, A., and Mohamed, R., 2013, Surface evidence supporting a probable new concept to the river systems evolution in Egypt: A remote sensing review, Environmental Earth Sciences, 69 (5) pp. 1621-1635.

APHA, (American Public Health Association), 2017, Standard method for the estimation of water and wastewater, $21^{\text {th }}$ edition, American Public Health Association, New York, USA.

APHA, AWWA, WEF, 2005, Standard method for the estimation of water and wastewater, $21^{\text {th }}$ edition, American Public Health Association, New York, USA.

Chebotarev's, I. I., 1955a, Metamorphism of natural waters in the crust weathering 1 , Geochimica et Cosmochimica Acta, 8(1): 22-32.

Chebotarev's, I. I., 1955b, Metamorphism of natural waters in the crust weathering 2, Geochimica et Cosmochimica Acta, 8(4): 198-212.

Continental Oil Company (CONOCO), 1987, Geological map of Egypt, scale 1:500000. Egyptian General Petroleum Authority (EGPA), Cairo, Egypt.

Dojlido, J. and G.A. Best, 1992, Chemistry of water and water pollution,Ellis Horwood series in water and waste water technology, New York-London.

Egyptian Meteorological Authority, 2006, Climatic Atlas of Egypt Published, Arab Republic of Egypt, Ministry of Transportation and communications.

El-Diary, M.D., 1980, Hydrogeological studies on the eastern part of Nile Delta using isotope techniques, M.Sc. Thesis, Fac. of Sci. Zagazig Univ., 233p.

El-Fakharany, M. A., 1997, Impact of groundwater quality on the corrosion of building foundations and pipes of water wells in the Nile Delta villages, Egypt, Egyptian. J. Geol., Vol. 41/2B: pp. 756-778.

El-Fakharany, M.A. and Mansour, N.M.,2009, Assessment of Water Resources Quality at the Southeastern Part of the Nile Delta, Egypt. International Conference on Water
Conservation in Arid Regions (ICWCAR 09) October 12 - 14, King Abdulaziz, Elsevier, Geoderma (149), pp. 409-414.

FAO, 2017, Water pollution for agriculture; a global review, Executive summary, the Food and Agriculture Organization of the United Nations Rome.

Hem, J. D., 1970, Study and interpretation of the chemical characteristics of natural water" U.S Geological Survey Water-Supply Paper.

Hem, J. D., 1985, Study and interpretation of the chemical characteristics of natural water, $3^{\text {rd }}$ edition, USGS.

McGowan,W., 2000, Water processing: residential, commercial, light-industrial, $3^{\text {rd }}$ edition, Lisle, IL, Water Quality Association.

Metwalli, M. H.,1963, The study of some Miocene sediments in the Cairo-Suez district, M. Sc. Thesis, Cairo Univ.,Egypt.

Nosair, A. M., 2011, Climatic changes and their impacts on groundwater occurrence in the northern part of east Nile Delta, Egypt.Unpublished M.Sc. Thesis, Zagazig Univ., Egypt.

Okonko, I.O., O.D. Adejoye, T.A. Ogunnusi, E.A. Fajobi and O.B. Shittu, 2008, Microbiological and physicochemical analysis of different water samples used for domestic purposes in Abeokuta and Ojota. Lagos State, Nigeria. Afr. J. Biotechnol., 7(3): pp. 617-621.

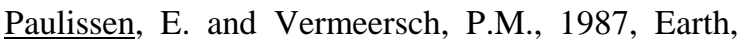
man and climate in the Egyptian Nile valley during the Pleistocene, Enclose, A.E., Editor, 1987, Prehistory of Arid North Africa, Southern Methodist University, Dallas, TX, pp. 29-68.

Piper, A.M., 1944, A graphic procedure in the geochemical interpretation of water analyses. American Geophysical Union Transactions, U.S.A. (25): , pp. 914-923.

Probe, L. M., Bruce, B. W., and Hansen, C. V., 1999, Groundwater quality in Quaternary deposits of the central high plains aquifer, south-central Kansas, U.S. Geol. Surv.

Richman, M., 1997, Industrial water pollution, Wastewater, 5(2): pp. 24-29. 
Research Institute for Groundwater (RIGW), 1989, Hydrogeological map of Egypt, scale 1: $100,000,1^{\text {st }}$ edition, map sheet of Cairo.

Research Institute for Groundwater (RIGW), 1992, Hydrogeological Map of Egypt, Scale $1: 100,000.2^{\text {nd }}$ edition.

Said, R., 1962, The Geology of Egypt, Elsevier Publishing Co., Amsterdam, 377 p.

Said, R., 1981, The Geological Evolution of the River Nile, Springer, New York, 151p.

Said, R., 1990, The Geology of Egypt, A.A. Balkema, Rotterdam/Brookfield, 734 p.

Shata, A. and El Fayoumy, I.F., 1970, Remarks on the Regional Geological Structure of Nile Delta, Proceeding of the Bucharest Symposium on Hydrogeology of Deltas, 1, pp.189-197.

Shukri, N.M. and Akmal, M.G.,1953, Geology of Gebel El-Nassuri and Gebel El-Anqabia district, Bull. Soc. Geoph. Egypt, Vol. 26, pp. 243-276.

Shukri, N. M. and El-Ayouti, 1956, The mineralogy of Eocene and later sediments in the Anqabia area, Cairo-Suez district, Bull.Ac. Sci., Cairo Univ., Vol. 32, pp. 47-61.

U.S. EPA, 2001, Contaminant Candidate List Preliminary Regulatory Determination Support Document for Manganese, U.S. Environmental Protection Agency, Office of Water, Washington, DC. November, 2001 (EPA 815-R-01-013).

World Health Organization (WHO), 2004, Guideline for drinking water quality, $3^{\text {rd }}$ edition, Vol. I, Recommendations, Geneva. 